\title{
特集 (I)：資料の収集
}

\section{八 尋 重 久*}

図書館は研究者に対しては奉仕機関であ り，学生には教育機関である。この目的にそ って充分な図書館機能を発揮するには, 学術 研究の方向, および教育課程を常に認識し て，計画的に広い視野から文献資料の収集を しなければならない。

\section{I ・リザーブブック}

科学研究の飛躍的な発展により, 研究分野 は拡大専門化してきていて同一教室または講 座に拈いても, 研究主題, 講義内容が指導教 官個々によって相異している。そのため教育

(講座) 単位でなく, 教授, 助教授および講 師全員に教室図書主任を通して, Text-Book, Reference Book を每年定期的に調查を行な いReserve Book の拡大充実に努めている。 この調査は要求資料をつかむだけでなく，学 生に対する Information の活動をするらえ の重要な参考資料として子利用する。Louis Round Wilson などは「大学図書館の集書は 教授目的と照し合せてみて，その有効性につ いて，定期的に再検討をする必要がある。こ れは学問のそれぞれの分野に挑将る図書館資 料について調査すると同時に，学生並びに教 授の利用について子調查するものである」と 述べている。

カリキュラムは永久に変化しないものでは なく，学問の発展に比例して更新される流動 的性格のものである。そのため戍書館は常に カリキュラムの内容を周知し，その進行方向 にマッチしたリザーブブックの収集をするこ とは当然である。

\footnotetext{
* Shigehisa YAHIRO, 九大矤学図害館
}

教官にアンケートを求めると同様，利用す る学生に対しても学生図書委員を介して要求 文献の調查を行っている。今年度要求された リザーブブックを執管者の職種別に分けた結 果は次のと和りである。ただしこれは和書に ついである。

\begin{tabular}{c|c|c}
\hline 執筆者の職種 & 冊 数 & 比 率 \\
\hline 大学, 付属機関 & 366 & 46 \\
(九大関係) & $(175)$ & $(48)$ \\
(他大 学) & $(191)$ & $(52)$ \\
\hline そ & 冊 & $\%$ \\
\hline
\end{tabular}

この表が示す如く要求された図書の殆どが 大学教授等によって執筆されたものである。

現職から退かれた名誉教授等により執筆に なった図書は 9 冊しかなく，全て後任者が改 稿したものである。このことは現在のカリキ ニラムに合致した図書が学生に理解し易く, 医学の日進月歩により常に畫き改奻られてい るからと言光る。

和書のリザーブブックの利用の高度化を促 進するには母体機関の現職教官の著作物を収 集することである。次に他大学関係教官の著 書を充実することにある。外国図畫もこの傾 向と大体同じことが言える。

\section{II. 新刊書情報による要求}

Academic Press のカード型, Livingston の揭示，経込み用紙型など各種のフォームの 新刊書予告, 紹介案内状が各出版社, 歕売店 
から相当量配達されてくる。また文献の中に 経込及式のものもある。これら全てを検討す ることは量が多く片手間には完全に行ない難 いが，可能な限り素読し必要と思われる情報 は次の方法をとっている。

[学生]前記の如く学生の利用する, また利 用させるべき図書は，定期的な調査に基づい て備付けた図書で，特に不便は与えていな い。また子算的にも限られているため備付け る数にも自ら限度がある。しかし読書研究会 や学習に必要とする文献の出版案内広告は一 階新聞閲覧室に揭示，展示して通覧できるよ らにしている。この中に備付希望するものが あるときは「購入希望図書申込書」によって 要求すればよい。ここに要求されてくる図書 の利用率は多くなく，専門分野でなく関係領 域部門の図書が大部分であるため，購入する には要求された図書の内容をできる限り関係 教室に問合わせることにしている。

[教官・研究者] 專門的研究図書の情報は力 タログを添付した「新刊案内書」を当該教室 図書主任に回覽し，備付希望の有無の回答を 受けている。

図書館の図書購入費の相当額は学生用関係 図書を購入することが基本であり，またそれ 位の予算しか配分されず，研究図書には教室 経費で購入することになっているため，図書 館で購入するものは各科に共通な図書に大体 限られているので，只情報を流し教室で購入 する参考供するのみに止なっている。

\section{III. 図書館と教室の図書購入額 (雑誌费仙)}

教室図書購入予算が図書館経費の約 5 倍で ある。何故このような現象が生じているかを 考察すれば教室の建物が各々独立した位置に あること，また学生用中央図書室は設置され ていたが，研究者が文献を共通に利用し得る 場，即ち研究者のための図書館が学部創設後 約 50 年間設置されなかったことに起因して いると思う。そのため教室個々の方法によっ
て購入せざるを得ないことになり，その習慣 が現在まで継続しているのでなかららか。こ れを改善する趣旨の一つとして図書館が設置 になり，集中管理方式に徐々に切替えている が，地理的配置の問題などの事情が是正され ない限り集中制の完全実施は困難である。し かし，不必要な図書の重複購入を回避するら えにも，文献の集中利用制によってより効果 的図書館サービスを促進するためにも何らか の措置を講じなければならない。

\begin{tabular}{|c|c|c|c|}
\hline & 昭35年度 & 昭36年度 & 昭37年度 \\
\hline 図晝 館 & $\begin{array}{c}\text { 千円 } \\
862 \\
(1.5)\end{array}$ & $\begin{array}{l}\underset{1}{\text { 千円 }} \\
(1.8)\end{array}$ & $\begin{array}{c}\text { 千丽 } \\
98 \\
(1.5)\end{array}$ \\
\hline 教 室 & $\begin{array}{c}\text { 千円 } \\
4,749 \\
(8.5)\end{array}$ & $\begin{array}{l}\text { 千円 } \\
5,137 \\
(8.2)\end{array}$ & $\begin{array}{l}\text { 千円 } \\
5,369 \\
(8.5)\end{array}$ \\
\hline
\end{tabular}

それまでの暫定措置として「各教室所蔵文 献の共通利用規則」を作成し独占的使用を排 除した。Douglas W Bryant は次のように 述べている。「個々の部局図書館がどのよう な地理的配置になっていようとも，大学図書 館全体が, 全大学の学生, 教授の利用に供さ れるべきものであることを強調することであ る。そのどの部分も，ある専門的グループの 利用物のように考它らてはならない」と。

「図書館とすればまずかき集めることから スタートすることである。選択に和ける初歩 はリストを作成することである。最初は特に 興味が持たれる主題すべての雑誌りストを作 り，次に関係分野のものを所有する」と George Valerie は言っている。

共通利用をする場合の探索資料として所蔵 文献リストを作成して，散在している文献の 利用度を高めるとともに図書館の研究文献の 不足を補うことにした。 


\section{IV. 定期刊行物}

現在の受入種類数は 650 種 (外国雑誌) で あるが他館と比較して不充分である。例えば 医学図畫館協会の選定基準図書 84 種（現行 医学雑誌所在目録, 欧文篇 1962 年版) の中 数点, また米国 New York 地区医学図書館 の Core Journals 209 誌の中 54 誌, Harvard Univ. Medical Library の利用度の高い133 誌の中 25 誌（沙藤氏調）および他館に借用, 複写依頼の多いもの 12 種等がある。もっと も他館に所蔵しているから必ずしも同じもの を揃えると言うのではなく, 雑誌の重要性, 利用性を知るためである。

利用者の希望資料の要求調査を定期的に実 施しているが，これに希望されるものはある 特定分野の専門誌が多い。

また創刊雑誌のアドヴァーチスメントは 「New Journal 通知書」に添付し, 添付不 可能なのは編集者, 論文提供機関等を転写し て関係講座に送付し, 希望の有無を問合わせ る。この外資料の重要な情報源の Tools と して, Review, Abstracts など各種の書評雑 誌がある。

\section{$\mathbf{V}$. 購入文献の選択決定}

教授, 助教授および講師等によって構成す る図書委員会に赫いて図書館で購入する文献 をそれぞれの提出された資料を参考にして決 定する。

リザーブブックは各分野の希望順位, 即ち 石井秀雄氏の「集保用均衡型：集書計画, 保 管，資料供用の3つの機能の機械的な平均を 意味するのではなく，母体機関（利用者）の 要請に長くマッチした均衡をとる」を基本原 則にして購入する。

研究用に主として利用される逐次刊行物 は，全タイトルを購入し，かつ利用度の高い のは数部揃えることが理想であるかも知れな いが，限られた少ない経費では $1 / 4$ 程度しか 備えることはできない。また 3,000 種以上の
刊行物を1大学で全タイトルを備えることは 不可能である。福岡辰造氏は「雑誌, 文献 （特許を含む）は外部構造で収集するのでは なく, 内部構造の収集が真の意味の大学図書 館の性格である」と言われているが，現状に 抒ける収集は, 共通的利用度の高い雑誌であ っても1部しか備付けることはできない。

そのため利用者からの要求文献でも満足に 購入することはできない。要求文献の内容を つかむ前に如何にしたら主要な文献を購入す ることができるか。これが今の課題と思う。

\section{むすび}

選択の技術的な方法を検討することも重要 であるが，基本的重要な文献さえ充分購入で きない状態にある図書館にとっては選択以前 に解決すべき問題がある。

図書館は大学の教育, 研究センタ一の機能 を果す機関であると一般に観念的には普及さ れているが，実行は現実化されていない。日 本の大学図書館が欧米特にアメリカ図書館よ り2，30 年おくれていると言われる。いるい ろの原因があるだろらが，次のことが根本原 因でないかと思ら。

一つは教育制度にある。「日本の教育は戦 後全面的にアメリカの教育制度を採用した。 そのため高等学校以下の学校図書館は, アメ リカ的教育制度のもとに非常な発達を示して きた。大学も新制大学として新しく出発した が，教室に和ける教授法は以前として講義と 教科書にたよる方式であり, Teaching With Books の教育方法はとっていない。そこに日 本の大学図書館の発展を阻ばむ大きな障碍が ある」とアメリカ図書館研究調查団は報告し ている。

他の一つは図書館子算である。国立大学図 書館改善要項第 2 条に「大学図書館の予算は 大学総経費の少なくとも 10 パーセントを目 標とする経常費と，臨時的な特殊経費をもっ てする」と規定されているが，実際は 2 パー 
セント弱程度が配当されるに過ぎない。利用 者の要求資料を適格につかみ，収集文献の拡 大充実をはかって, 研究之調査, 学習之教養 の場としての図書館機能を遂行するには, 現 行の予算配分方法和よび教育制度を改正しな ければならない段階にある。そのことによっ て図書館サービスの核心となる有効的な文献 の収集沶よび利用の促進化がなされ，大学図 書館がますます発展するのである。

\section{参考資 料}

1）Wilson， L. R. \& et al. (渡辺正亥 - 星 野博改訳版)：大学の図書館。日本図書 館
協会, $1959:$ p. 9 10

2) Bryant, D. W. : 大学図書館の将来を語 る。東大図書館, 1963 : p. 17

3) Ashworth, W. (ed.): Handbook of Special Librarianship and Information Work, 2 nd ed. Aslib, 1962 : p. 40

4) 福岡辰造 : 薬学文献の収集について。薬 学図書館, Vol. $6: 66,1961$

5）石井秀雄：専門図書館の現状と問題点。 四書館雑誌，Vol. 58 : 92, 1964

6) アメリ力図書館研究調查団：アメリカの 図書館。1960：p. 38

\section{外国雑誌のこ案內 New Journals from Pergamon Press}

\section{IMMUNOCHEMISTRY}

an international journal-

Regional Editors: Dan H. Campbell, Pasadena, California; Alain Bussard, Paris, France; Henri Isliker, Switzerland; Fred Karush, Philadelphia, Pennsylvania

Quarterly 年間予約価 $¥ 18,900$

\section{EUROPEAN REVIEW OF ENDOCRINOLOGY}

an international journal-

Published simultaneously in French and English by GauthierVillars Ed., and Pergamon Press Ltd. for the European Association of Endocrinology.

Editors: Prof. A. Soulairac, Paris, \& M. Marois, Paris.

2 Nos. 年間予約価 $¥ 13,200$

\section{(19) 外国雑誌部}

